\title{
$\mathrm{LR}=$ INTERNATIONAL JOURNAL OF ACADEMIC \\ HUMAN RESOURCE
MAAAGEMENACADEMIC
BESEARCH SOCIETY

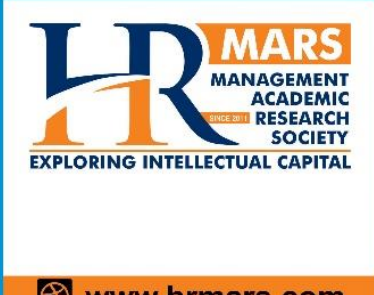

Www.hrmars.com

\section{Assessing Financial Reporting Quality of Company Limited by Guarantee Charities in Malaysia Using Benford's Law: A Preliminary Study}

Sharon Cheuk, Esmie O. Nichol, Daw Tin Hla \& Michael Tinggi

To Link this Article: http://dx.doi.org/10.6007/IJARAFMS/v11-i2/10047 DOI:10.6007/IJARAFMS /v11-i2/10047

Received: 21 April 2021, Revised: 23 May 2021, Accepted: 09 June 2021

Published Online: 28 June 2021

In-Text Citation: (Cheuk et al., 2021)

To Cite this Article: Cheuk, S., Nichol, E. O., Hla, D. T., \& Tinggi, M. (2021). Assessing Financial Reporting Quality of Company Limited by Guarantee Charities in Malaysia Using Benford's Law: A Preliminary Study. International Journal of Academic Research in Accounting Finance and Management Sciences, 11(2), 156167.

\section{Copyright: (c) 2021 The Author(s)}

Published by Human Resource Management Academic Research Society (www.hrmars.com)

This article is published under the Creative Commons Attribution (CC BY 4.0) license. Anyone may reproduce, distribute, translate and create derivative works of this article (for both commercial and non-commercial purposes), subject to full attribution to the original publication and authors. The full terms of this license may be seen at: $\underline{\text { http://creativecommons.org/licences/by/4.0/legalcode }}$

Vol. 11, No. 2, 2021, Pg. 156 - 167

Full Terms \& Conditions of access and use can be found at http://hrmars.com/index.php/pages/detail/publication-ethics 


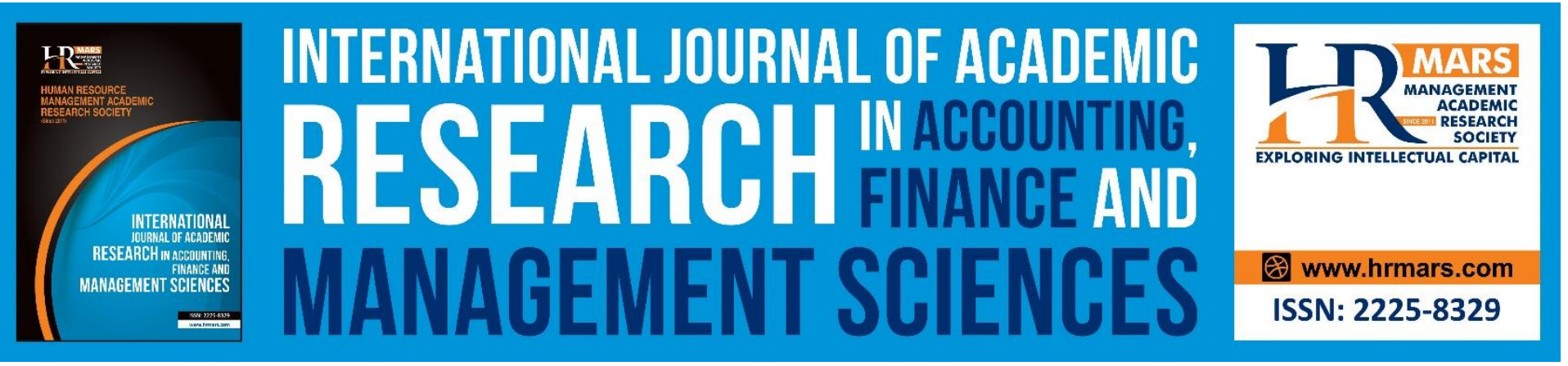

\title{
Assessing Financial Reporting Quality of Company Limited by Guarantee Charities in Malaysia Using Benford's Law: A Preliminary Study
}

\author{
Sharon Cheuk, Esmie O. Nichol, Daw Tin Hla \& Michael Tinggi
}

Faculty of Economics and Business, Universiti Malaysia Sarawak, Malaysia

Email: ccssharon@unimas.my

\begin{abstract}
The issue of terrorism is experienced at the global level, and it has been recognised that such activities need financing from various sources, legitimate and illegitimate. A legitimate source is via non-profit organisations. It has been advocated that effective investigation and information gathering be done at the country-level to facilitate the detection of terrorist abuse of non-profit organisations; such information would include financial information. In view of the foregoing, a comprehensive assessment of the financial reporting quality of non-profit organisations would be a useful step in conducting an overall risk analysis of the non-profit sector. The objective of this study is to assess the financial reporting quality of charities in Malaysia. The financial statements of 235 companies limited by guarantee were extracted for the years 2016, 2017 and 2018 resulting in 7,056 observations. Digital analysis was performed to review the conformity of first and second digit distributions with that of Benford's Law; the main statistics of the log mantissa and the Mean Absolute Deviation were also computed. Subsequently, statistical tests were run to evaluate data conformity to Benford's Law. Findings were found to be mixed and inconclusive. Implications of the study's findings and suggestions for further research were further discussed.
\end{abstract}

Keywords: Financial Reporting Quality, Benford's Law, Companies Limited by Guarantee, Charities, Malaysia

\section{Introduction}

Terrorism is an ongoing global issue, and there have been many terrorism-caused incidents in recent times. Of course, the incident that remains in the global psyche is the September 11 Twin Tower attack in 2001. Since then, there have been numerous incidents in the Asian region. For example, the Abu Sayaaf group had been committing criminal acts of bombings, kidnappings, assassinations and extortions from the early 1990's until the present day, in the Phillippines and Malaysia (Wikipedia, n.d.). The latest recorded terrorism incident in the South East Asian region was on 28 March 2021 which involved a church cathedral bombing in Makassar, Indonesia during a Sunday service, allegedly caused by an ISIL-linked group Jamaah Ansharut Daulah (Sriregar, 2021). 
INTERNATIONAL JOURNAL OF ACADEMIC RESEARCH IN ACCOUNTING, FINANCE AND MANAGEMENT SCIENCES

Vol. 11, No. 2, 2021, E-ISSN: 2225-8329 @ 2021 HRMARS

Terrorism as an activity needs to be funded. Such funds are usually sourced using legitimate or illegitimate means. One such legitimate means is via non-profit organisations (Bank Negara Malaysia, n.d.). According to the Financial Action Task Force (FATF), the global money laundering and terrorist financing watchdog, funds generated through non-profit organisations may be collected but disbursed for terrorist activities. Also, a non-profit organisation may be used as a money laundering vehicle to transmit funds between various locations (Financial Action Task Force, 2008). The FATF advocates, amongst other things, the effective investigation and information gathering be done at the country-level, making use of multiple types of information from different sources which facilitates the detection of terrorist abuse of non-profit organisations; such information would include financial information. In view of the foregoing, a comprehensive assessment of the financial reporting quality of non-profit organisations, using a method that can highlight the presence of financial irregularities, would be a useful step in conducting an overall risk analysis of the non-profit sector as a whole. Therefore, the objective of this study is to assess the financial reporting quality of non-profit organisations (charities in particular) in Malaysia, making use of Benford's analysis.

\section{Literature Review}

Benford's Law is an observation on the leading digits of naturally generated numerical data, that such data will naturally follow a particular distribution pattern whereby digit 1 will occur $30.1 \%$ of the time, and digits 2 to 9 will occur 17.6\%, 12.5\%, 9.7\%, 7.9\%, 6.7\%, 5.8\%, 5.1\% and $4.6 \%$ of the time respectively (Benford, 1938). The Benford distribution is matched with that of real data sets; real data distributions that deviate from that of the Benford distribution would appear to indicate data anomalies. Benford's Law has been utilised to verify economic data (e.g. Varian, 1972; Rauch, Göttsche, Brähler and Engel, 2011), election results (e.g. Myagkov, Ordeshook and Shakin, 2005), surveys (e.g. Judge and Schechter, 2009; Finn and Ranchod, 2017).

In accounting, Benford's Law has been used for detecting financial irregularities in accounting data. For instance, it was used to supplement analytical procedures in the area of auditing (Nigrini and Mittermaier, 1997; Drake and Nigrini, 2000), fraud detection (Durtschi, Hillison and Pacini, 2004; Moore and Benjamin, 2004; Cleary and Thibodeau, 2005; Mehta and Bhavani, 2017; Gabrielli and Medioli, 2019), accounting data manipulation (Grammatikos and Papanikolaou, 2021) and to examine taxpayer compliance (Nigrini, 1996). It has also been used to assess the financial reporting quality of entities from a general perspective (e.g. Lin, Wang and Lin, 2018; Shi, Ausloos and Zhu, 2018; Jianu and Jianu, 2021).

It is also applied in the non-profit environment, such as the public sector (Aris, Othman, Mohd Bukhori, Mohd Arif and Abdul Malek, 2017) and the third sector (Caneghem, 2016; Qu, Steinberg and Burger, 2019), and amongst these studies, two focused on financial reporting quality (Caneghem, 2016; Qu, Steinberg and Burger, 2019).

The financial reporting quality of the non-profit sector in Malaysia has not yet been studied from the perspective of Benford's analysis. Therefore, this study aims to fill the identified gap. 


\section{Methodology}

The population of this study is charities and the sampling frame will be the full listing of charities. Such charities comprise of companies limited by guarantee (CLBG) registered with the Companies Commission of Malaysia (CCM). CLBGs are non-profit organisations which do not have shareholders, but are guaranteed by directors. CLBGs (and not other types of charitable entities, such as societies) are chosen as they are larger in size and more funds are required to set up a CLBG as compared to other non-profit organisations such as societies. According to Guidelines on Companies Limited by Guarantee issued by CCM, an initial fund of RM1 million in cash has to be made within 6 months from the date of incorporation. Also, non-profits with revenue of more than RM1 million are usually registered as CLBGs whereby non-profits with revenue less than RM1 million are usually registered with the Registry of Societies Malaysia (Arshad, Abu Bakar, Thani and Omar, 2013). As such, any incidences of financial irregularity will be more significant and critical in CLBGs.

The data for analysis is manually extracted from the financial statements (statement of profit and loss and statement of financial position) of all CLBGs for the years 2016, 2017 and 2018. The financial statements were submitted on an annual basis to the Companies Commission Malaysia (CCM). A sample of 7,056 observations was obtained as a result.

At this point, it is pertinent to note why Benford's analysis is suitable for the study data. Firstly, it has been noted that data will follow Benford's law when the numbers are: (i) composites of naturallygenerated data in numerous steps (Hill, 1998); (ii) not restricted such as having maximum or minimum limits and number assignments; and (iii) not subject to human or psychological influence. Accounting data would fall into such a data distribution (Durtschi et al., 2004).

Digital analysis was performed on the data to review the conformity of first and second digit distributions with that of Benford's data distribution. The first and second digit tests are high-level tests of reasonableness of the data set. Theoretical and observed distributions were then plotted for a graphical comparison. Also, the main statistics of the log mantissa, as well as the Mean Absolute Deviation (MAD) are computed. The STATA package was used to analyse the digit distribution (Jann, 2007).

Subsequently, statistical tests were run to evaluate data conformity to Benford's Law using the benford.analysis (Cinelli, 2018) and BenfordTests (Joenssen, 2015) packages within the R package ( $R$ Core Team, 2021).

\section{Results}

The first digit and second digit tests are high-level tests that assess overall conformity. Table 1 and Figure 1 depict the results of the comparison of the first digit frequencies in the dataset against the Benford distribution. The first digit distribution of the study data would appear to be largely consistent with that of Benford, other than that for the values 1, 4 and 6 . As for the second digit distribution, the study data shows a general consistency with that of Benford, other than for the values 0, 1, 4 and 7 (see Table 2 and Figure 2). 
INTERNATIONAL JOURNAL OF ACADEMIC RESEARCH IN ACCOUNTING, FINANCE AND MANAGEMENT SCIENCES

Vol. 11, No. 2, 2021, E-ISSN: 2225-8329 @ 2021 HRMARS

Table 1: Distribution of first digits

\begin{tabular}{r|rrrr}
\hline Value & Count & $\begin{array}{r}\text { Percent } \\
\text { observed }\end{array}$ & $\begin{array}{r}\text { Percent } \\
\text { expected }\end{array}$ & Difference \\
\hline $\mathbf{1}$ & 2,281 & 32.327 & 30.103 & 2.224 \\
$\mathbf{2}$ & 1,228 & 17.404 & 17.609 & -0.205 \\
$\mathbf{3}$ & 904 & 12.812 & 12.494 & 0.318 \\
$\mathbf{4}$ & 633 & 8.971 & 9.691 & -0.720 \\
$\mathbf{5}$ & 545 & 7.724 & 7.918 & -0.194 \\
$\mathbf{6}$ & 413 & 5.853 & 6.695 & -0.842 \\
$\mathbf{7}$ & 374 & 5.300 & 5.799 & -0.499 \\
$\mathbf{8}$ & 366 & 5.187 & 5.115 & 0.072 \\
$\mathbf{9}$ & 312 & 4.422 & 4.576 & -0.154 \\
\hline Total & 7,056 & 100.000 & 100.000 & 0.581 \\
\hline
\end{tabular}

Table 2: Distribution of second digits

\begin{tabular}{r|rrrr}
\hline Value & Count & $\begin{array}{r}\text { Percent } \\
\text { observed }\end{array}$ & $\begin{array}{r}\text { Percent } \\
\text { expected }\end{array}$ & Difference \\
\hline $\mathbf{0}$ & 1,198 & 17.173 & 11.968 & 5.205 \\
$\mathbf{1}$ & 723 & 10.364 & 11.389 & -1.025 \\
$\mathbf{2}$ & 719 & 10.307 & 10.882 & -0.575 \\
$\mathbf{3}$ & 678 & 9.719 & 10.433 & -0.714 \\
$\mathbf{4}$ & 625 & 8.959 & 10.031 & -1.072 \\
$\mathbf{5}$ & 697 & 9.991 & 9.668 & 0.324 \\
$\mathbf{6}$ & 628 & 9.002 & 9.337 & -0.335 \\
$\mathbf{7}$ & 544 & 7.798 & 9.035 & -1.237 \\
$\mathbf{8}$ & 599 & 8.587 & 8.757 & -0.170 \\
$\mathbf{9}$ & 565 & 8.099 & 8.500 & -0.401 \\
\hline Total & 6,976 & 100.000 & 100.000 & 1.106 \\
\hline
\end{tabular}


INTERNATIONAL JOURNAL OF ACADEMIC RESEARCH IN ACCOUNTING, FINANCE AND MANAGEMENT SCIENCES

Vol. 11, No. 2, 2021, E-ISSN: 2225-8329 @ 2021 HRMARS

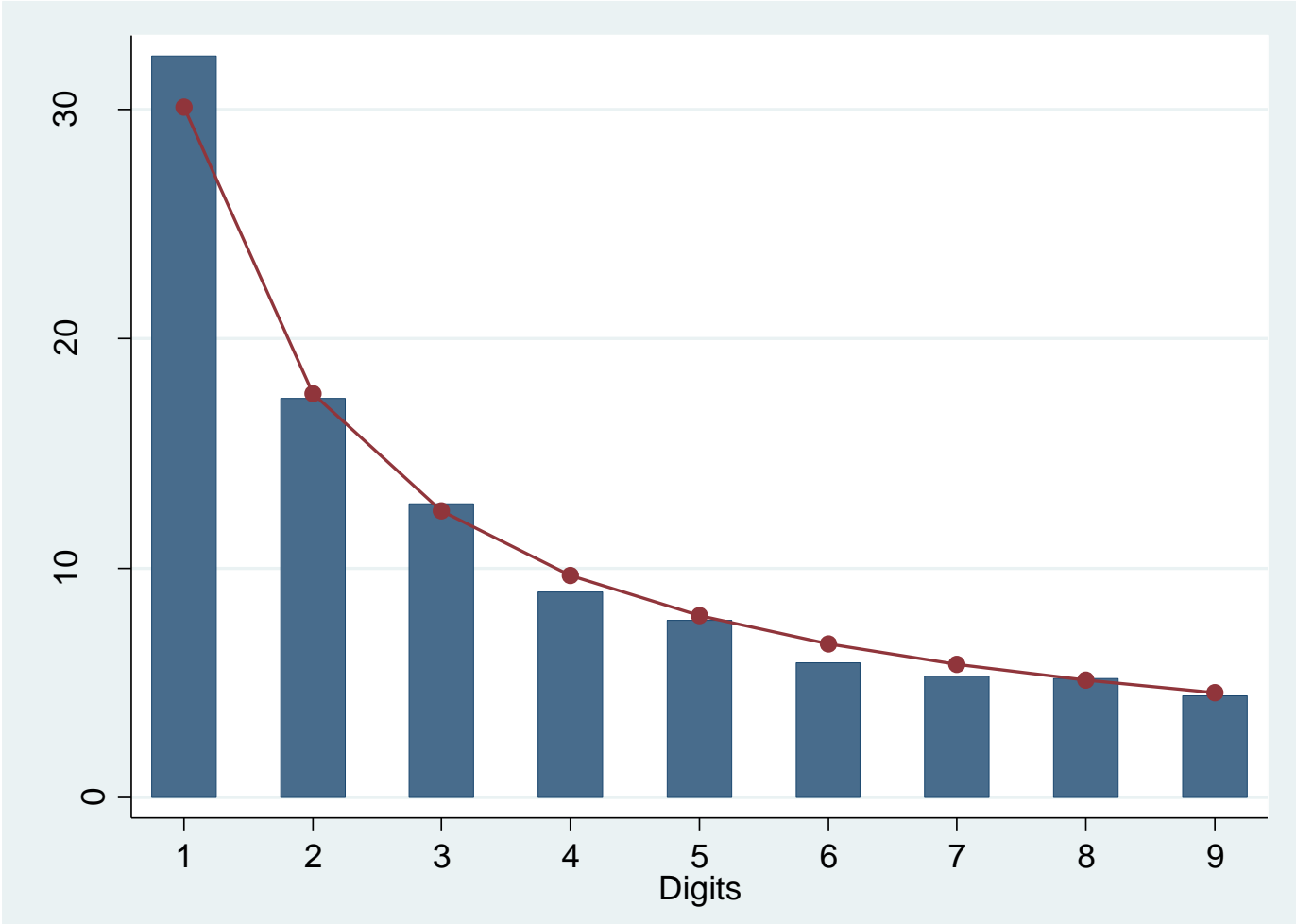

Figure 1: Graph of distribution of first digits

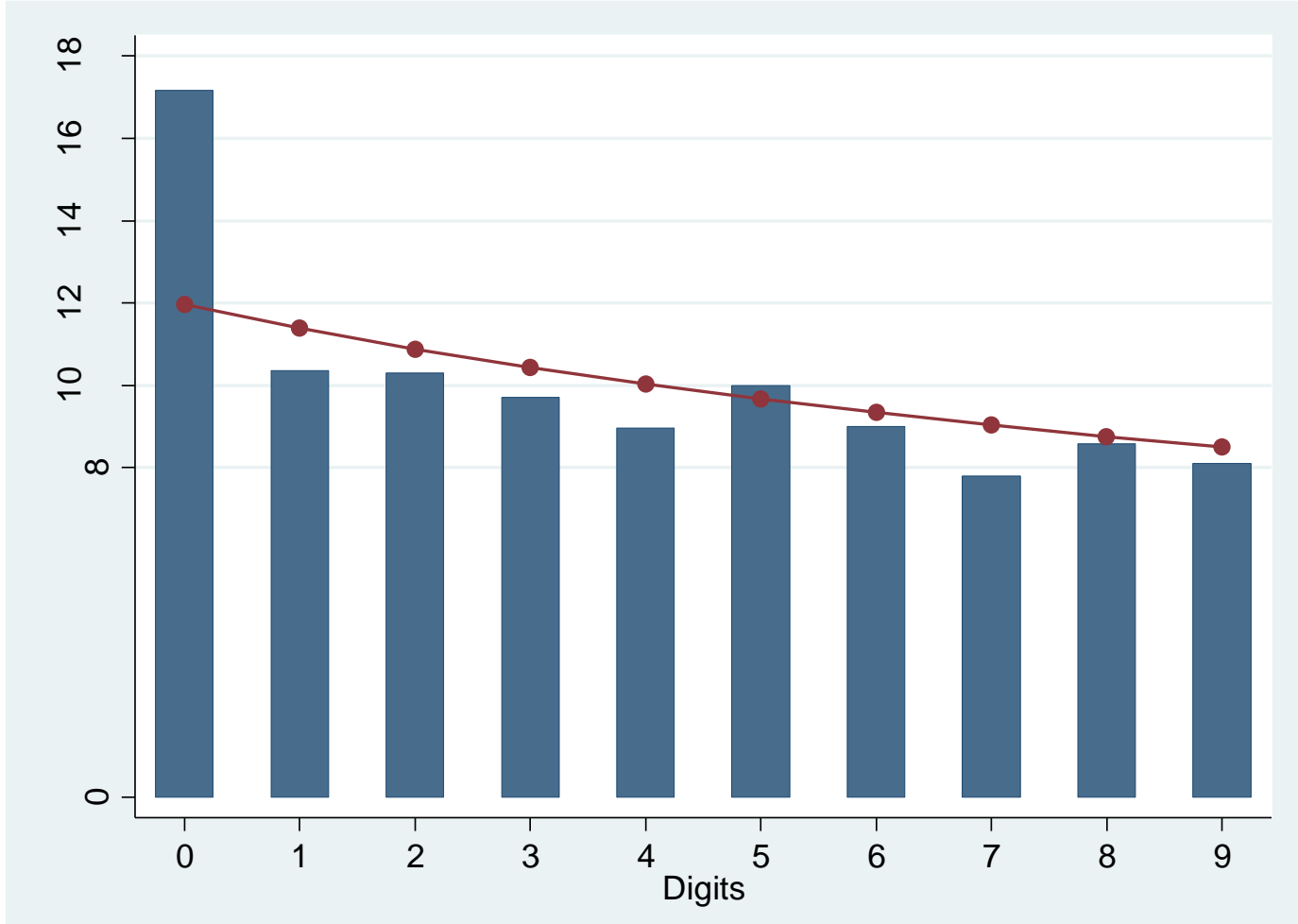

Figure 2: Graph of distribution of second digits 
INTERNATIONAL JOURNAL OF ACADEMIC RESEARCH IN ACCOUNTING, FINANCE AND

\section{MANAGEMENT SCIENCES}

Vol. 11, No. 2, 2021, E-ISSN: 2225-8329 @ 2021 HRMARS

The main statistics of the log mantissa (Cinelli, 2018) are as follows: mean 0.48, variance 0.086 , excess kurtosis -1.195 and skewness 0.051. Other than skewness, the main statistics are close to that exhibited by Benford data (mean 0.5, variance 0.083, excess kurtosis -1.2, skewness 0 ). Another descriptive measure, the Mean Absolute Deviation (MAD) (Nigrini, 2012), is also calculated. A MAD value of 0 to 0.006 suggests close conformity to Benford's Law, 0.006 to 0.012 shows acceptable conformance, 0.012 to 0.015 suggests marginally acceptable conformity, and beyond 0.015 indicates non-conformance. The MAD statistics for the first digit distribution of study data is 0.0058 , indicating close conformity and 0.0019 for the first two digit distribution, indicating marginally acceptable conformity.

To test the goodness of fit, the following statistical tests were employed. The hypotheses considered are as follows:

H0: The population's first digit and/or first two digits distributions conform to Benford's Law and H1: The population's first digit and/or first two digits distributions are different from Benford's Law.

Statistical tests are done on the first two digit distributions as well as only the first digits, as it has been noted that anomalies in data that is falsified are significantly more obvious in the second digits than they are in the first (Mosimann et al., 1995; Diekmann, 2007, van Caneghem, 2016). A range of tests are performed for a more accurate analysis of data conformity, as tests like chi-square and Kolmogorov-Smirnov are more sensitive to size of the data set (Boero, Smith and Wallis, 2005; Ahad, Teh, Othman \& Yaacob, 2011). 
INTERNATIONAL JOURNAL OF ACADEMIC RESEARCH IN ACCOUNTING, FINANCE AND MANAGEMENT SCIENCES

Vol. 11, No. 2, 2021, E-ISSN: 2225-8329 @ 2021 HRMARS

Table 3 presents the results of the statistical tests, at 95\% confidence level.

Table 3: Statistical test results

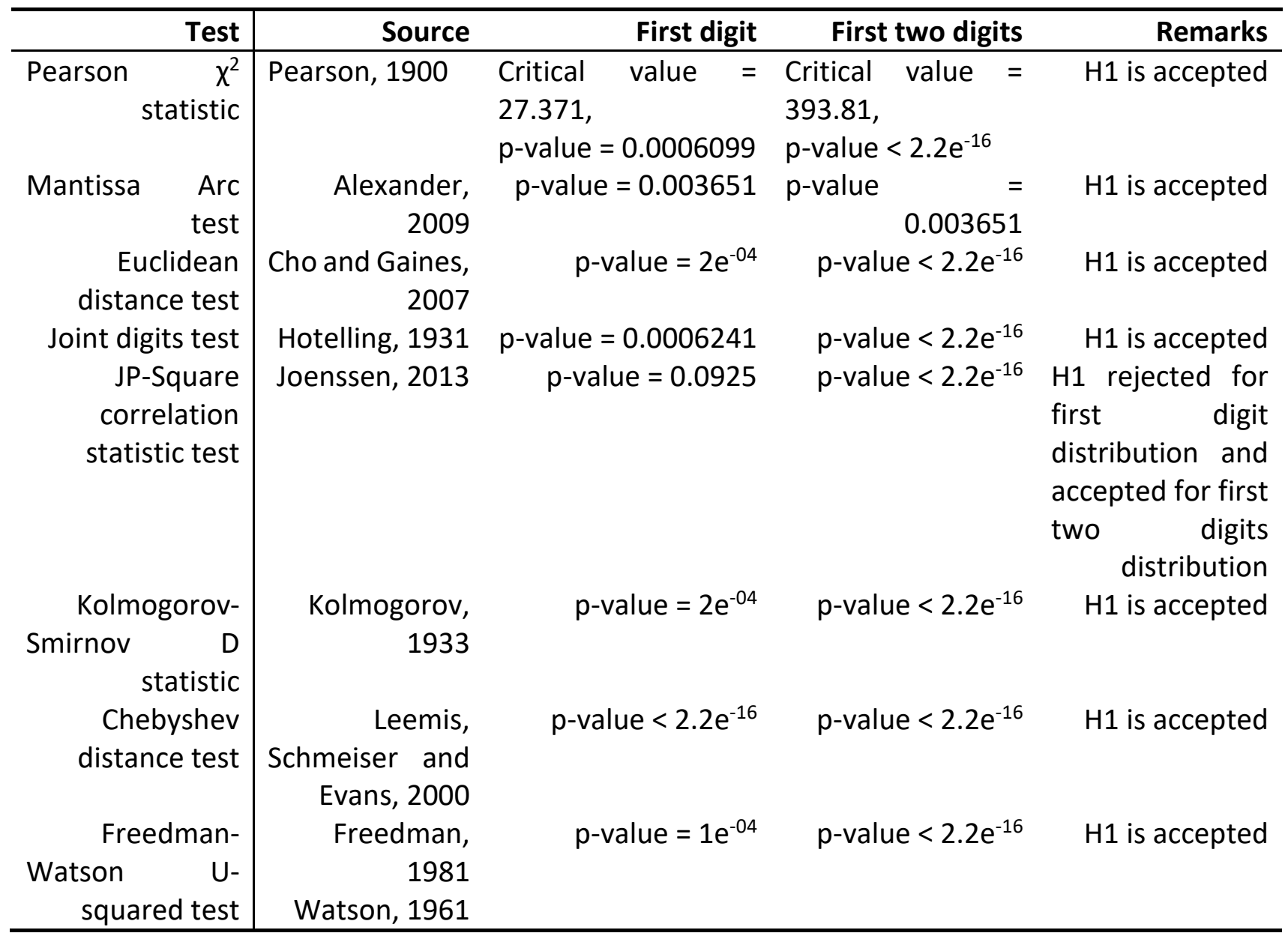

The review of the graphical representation of the first digit distribution of the study data would appear to indicate that the study data set is reasonably consistent with that of Benford. The second digit distribution is also largely consistent, other than for the value 0 . The main statistics of the log mantissa and Mean Absolute Deviation also showed reasonable conformity of the study data with that of Benford.

However, statistical tests showed otherwise. All statistical tests run indicated that $\mathrm{H} 1$ is to be accepted, that is the population's first digit and/or first two digits distributions are different from Benford's Law. One exception is that of the JP-Square correlation statistic test which indicated that the study data conforms to Benford for the first two digits distribution but not for first digit distribution.

\section{Discussion and Conclusion}

In conclusion, this study notes mixed findings for financial reporting quality of charities, as measured by conformity of the financial statement numbers, in the context of companies limited by guarantee 
INTERNATIONAL JOURNAL OF ACADEMIC RESEARCH IN ACCOUNTING, FINANCE AND

MANAGEMENT SCIENCES

Vol. 11, No. 2, 2021, E-ISSN: 2225-8329 @ 2021 HRMARS

in Malaysia. When reviewing the observed deviations in the second digit distribution, it can be noted that zeros and fives occur more frequently than predicted, while all other deviations are negative. The disproportionate occurrences of zero in the second digit position would appear to indicate rounding up behaviour, whereby managers tend to round up numbers to multiples of ten which serve as cognitive reference points (Rosch, 1975). This is consistent with the findings of Aerts, Van Campenhout and Van Caneghem (2008) and Caneghem (2016). The higher than expected frequency of the number five occurring in the second position suggests that 5 also acts as a reference point to which numbers are rounded up to.

The contribution of this study lies in the study of the financial reporting quality amongst non-profit organisations in Malaysia, in particular, companies limited by guarantee, using Benford's analysis as a method, indicator and benchmark. Financial reporting quality of nonprofit organisations in Malaysia has been much studied, but not from the perspective of Benford's Law. Hence, this study fills such a gap. The findings of this study is expected to add to the body of literature on nonprofits as well as to financial reporting quality measurement.

The findings only indicate inadequacies in the general financial reporting quality of charities, which cannot be directly attributed to fraud or irregularities in financial reporting without further investigation. A possible next step is to conduct an analysis at the organisational level using financial data over a longer time. It is also possible to conduct an analysis at the variable level, for certain variables that may be of particular interest to stakeholders, such revenue and expenses. Such analysis can be conducted at a more detailed level, subject to data availability. For instance, revenue can be further analysed into the main sources of revenue, such as donations, commercial income, and others. A similar treatment can be made for expenses.

Charities can also be categorised and the related data could be analysed on a pooled basis. As mentioned in the Introduction, many past terrorism activities have had their roots in religious extremism. In view of the foregoing, it would be pertinent to divide the charities into religious and non-religious categories to see if financial reporting quality is comparatively worse amongst the religious charities. If found to be the case, an avenue for further research would be the motivation of the management of such charities pertaining to financial reporting in particular, and to financial management in general.

A limitation of this study lies in time period covered, which is 2017 to 2019. Although the data obtained was adequate in quantity, extending the time period should serve to provide a better representation of the financial reporting quality of the population under study. Another constraint is that the research population is made up of companies limited by guarantee; charities can also take the shape of societies or organisations. Future research could expand the sample size to improve the generalisability of the findings. Conducting interviews with important respondents from the sample selected could provide additional validation of the study's findings.

\section{Acknowledgement}

This study was fully supported by Universiti Malaysia Sarawak (UNIMAS) Grant No. F01/SpSTG/1578/2017. 
INTERNATIONAL JOURNAL OF ACADEMIC RESEARCH IN ACCOUNTING, FINANCE AND

MANAGEMENT SCIENCES

Vol. 11, No. 2, 2021, E-ISSN: 2225-8329 @ 2021 HRMARS

\section{References}

Aerts, W., Van Campenhout, G., and Van Caneghem, T. (2008). Clustering in dividends: Do managers rely on cognitive reference points? Journal of Economic Psychology, 29, 276-284.

Ahad, N. A., Teh, S. Y., Othman, A. R., \& Yaacob, C. R. (2011). Sensitivity of Normality Tests to Nonnormal Data. Sains Malaysiana, 40(6), 637-641.

Alexander, J.C. (2009). Remarks on the Use of Benford's Law. Available at SSRN: https://ssrn.com/abstract=1505147 or http://dx.doi.org/10.2139/ssrn.1505147

Aris, N. A., Othman, R., Bukhori, M. A., Arif, M. S. M., and Abdul Malek, M. A. (2017). Detecting Accounting Anomalies Using Benford's Law: Evidence from the Malaysian Public Sector. Management \& Accounting Review, 16(2), 73-99. doi: http://dx.doi.org/10.24191/mar.v16i2.666

Arshad, R., Abu Bakar, N., Thani, N. Y., and Omar, N. (2013a). Board Composition And Accountability Of Non-Profit Organisations. Journal of Applied Business Research (JABR), 29(4), 1021-1030.

Benford, F. (1938). The law of anomalous numbers. Proceedings of the American Philosophical Society, 78(4), 551-572.

Boero, G., Smith, J., \& Wallis, K.F. (2005) The Sensitivity of Chi-Squared Goodness-of-Fit Tests to the Partitioning of Data, Econometric Reviews, 23(4), 341-370, DOI: 10.1081/ETC-200040782

Cho, W. K. T., and Gaines, B. J. (2007) Breaking the (Benford) Law: Statistical Fraud Detection in Campaign Finance. The American Statistician, 61, 218-223.

Cleary, R., and Thibodeau, J. C. (2005). . Applying Digital Analysis Using Benford's Law to Detect Fraud: The Dangers of Type I Errors. Auditing, 24(1), 77-81.

Cinelli, C. (2018). benford.analysis: Benford Analysis for Data Validation and Forensic Analytics. R package version 0.1.5. https://CRAN.R-project.org/package=benford.analysis

Diekmann, A. (2007). Not the first digit. Using Benford's Law to detect fraudulent scientific data. Journal of Applied Statistics, 34, 321-329.

Drake, P. D., and Nigrini, M. J. (2000). Computer assisted analytical procedures using Benford's Law. Journal of Accounting Education, 18(2),127-146. https://doi.org/10.1016/S07485751(00)00008-7.

Durtschi, C., Hillison, W. A., \& Pacini, C. (2004). The effective use of Benford's Law to assist in detecting fraud in accounting data. Journal of Forensic Accounting, 5, 17-34. Financial Action Task Force (FATF) 2008. Terrorist financing. Paris: OECD/FATF

Finn, A., and Ranchod, V. (2017). Genuine fakes: The prevalence and implications of data fabrication in a large South African survey. World Bank Economic Review, 31(1), 129-157.

Freedman, L. S. (1981) Watson's U² Statistic for a Discrete Distribution. Biometrika, 68, 708-711.

Gabrielli, G., and Medioli, A. (2019). An Overview of Instruments and Tools to Detect Fraudulent Financial Statements. Universal Journal of Accounting and Finance, 7(3), 76-82. DOI: 10.13189/ujaf.2019.070302

Grammatikos, T., \& Papanikolaou, N. I. (2021). Applying Benford's Law to Detect Accounting Data Manipulation in the Banking Industry. Journal of Financial Services Research, 59, 115-142. https://doi.org/10.1007/s10693-020-00334-9

Hill, T. (1998). The First Digital Phenomenon. American Scientist, 86(4), 358-363.

Hotelling, H. (1931). The generalization of Student's ratio. Annals of Mathematical Statistics. 2, 360378. 
INTERNATIONAL JOURNAL OF ACADEMIC RESEARCH IN ACCOUNTING, FINANCE AND

MANAGEMENT SCIENCES

Vol. 11, No. 2, 2021, E-ISSN: 2225-8329 @ 2021 HRMARS

Jann, B. (2007). digdis: Stata module to analyze the distribution of digits. Available from http://ideas.repec.org/c/boc/bocode/s456853.html.

Jianu, I., and Jianu, I. (2021). Reliability of Financial Information from the Perspective of Benford's Law. Entropy. 23(5), 557. https://doi.org/10.3390/e23050557

Joenssen, D. W. (2013). Two Digit Testing for Benford's Law (Paper presentation). 59th ISI World Statistics Congress, Hong Kong (China). http://www.statistics.gov.hk/wsc/CPS021-P2-S.pdf

Joenssen, D. W. (2015). BenfordTests: Statistical Tests for Evaluating Conformity to Benford's Law. R package version 1.2.0. https://CRAN.R-project.org/package=BenfordTests

Judge, G., and Schechter, L. (2009). Detecting Problems in Survey Data Using Benford's Law. The Journal of Human Resources, 44(1), 1-24

Kolmogorov, A. N. (1933) Sulla determinazione empirica di una legge di distibuzione. Giornale dell'Istituto Italiano degli Attuari. 4, 83-91.

Leemis, L. M., Schmeiser, B. W., and Evans, D. L. (2000) Survival Distributions Satisfying Benford's law. The American Statistician. 54, 236-241.

Lin, L. J., Wang, T. S., and Lin, F. Y. (2018). Applying Digital Analysis to Corporate Governance and Financial Reporting Quality During Global Financial Upheavals. International Journal of Business \& Information, 13(3), 295-320.

Mehta, A., and Bhavani, G. (2017). Application of Forensic Tools to Detect Fraud: The Case of Toshiba, Journal of Forensic and Investigative Accounting, 9(1), 692-710.

Moore, G. B., \& Benjamin, C. O. (2004). Using Benford's Law for Fraud Detection. Internal Auditing, 19(1), 4-9.

Mosimann, J. E., Wiseman, C. V., and Edelman, R. E. (1995). Data fabrication: Can people generate random digits? Accountability in Research: Policies and Quality Assurance, 4, 31-55.

Myagkov, M., Ordeshook, P. C., \& Shakin, D. (2005). Fraud or fairytales: Russia and Ukraine's electoral experience. Post-Soviet Affairs, 21(2), 91-131.

Nigrini, M. J. (1996). A taxpayer compliance application of Benford's Law. The Journal of the American Taxation Association, 18(1), 72-91.

Nigrini, M. J. (2012). Benford's Law: Applications for Forensic Accounting, Auditing and Fraud Detection, Volume 586. New Jersey: John Wiley \& Sons.

Nigrini, M. J., and Mittermaier, L. (1997). The use of Benford's Law as an aid in analytical procedures. Journal of Auditing, 16(2), 52-67.

Pearson, K. (1900) On the Criterion that a Given System of Deviations from the Probable in the Case of a Correlated System of Variables is Such that it can be Reasonably Supposed to have Arisen from Random Sampling. Philosophical Magazine Series 5. 50, 157-175.

Qu, H., Steinberg, R., and Burger, R. (2019). Abiding by the Law? Using Benford's Law to Examine the Accuracy of Nonprofit Financial Reports, Nonprofit and Voluntary Sector Quarterly, 49(3), 548-570. https://doi.org/10.1177/0899764019881510.

Rauch, B., Göttsche, M., Brähler, G., and Engel, S. (2011). Fact and Fiction in EU-Governmental Economic Data. German Economic Review, 12(3), 243,255.

Rosch, E. (1975). Cognitive reference points. Cognitive Psychology, 7, 532-547.

Shi, J., Ausloos, M., \& Zhu, T. T. (2018). Benford's law first significant digit and distribution distances for testing the reliability of financial reports in developing countries. Physica A: Statistical Mechanics and its Applications, 492, 878-888. https://doi.org/10.1016/j.physa.2017.11.017. 
INTERNATIONAL JOURNAL OF ACADEMIC RESEARCH IN ACCOUNTING, FINANCE AND

MANAGEMENT SCIENCES

Vol. 11, No. 2, 2021, E-ISSN: 2225-8329 @ 2021 HRMARS

Sriregar, K. (2021). About 20 injured after suspected suicide bombing at Indonesian church. Channel News Asia. Retrieved from https://www.channelnewsasia.com/news/asia/two-suspectedsuicide-bombers-indonesia-church-injured-makassar-14509726

Van Caneghem, T. (2016). NPO Financial Statement Quality: An Empirical Analysis Based on Benford's Law. VOLUNTAS: International Journal of Voluntary and Nonprofit Organizations, 27, 2685-2708.

Varian, H. (1972). Benford's Law. The American Statistician, 25, 65-66.

Watson, G. S. (1961) Goodness-of-Fit Tests on a Circle. Biometrika. 48, 109-114.

Wikipedia. (n.d.). Abu Sayaaf. Retrieved May 14, 2021, from

https://en.wikipedia.org/wiki/Abu_Sayyaf 